\section{PÉNZÜGYI TUDATOSSÁG ÉS HOSSZABBODÓ NYUGDÍJAS ÉVEK BESZÁMOLÓ AZ IDEI NEMZETKÖZI AKTUÁRIUS KONGRESSZUSRÓL (BERLIN, 2018. JÚNIUS)}

Vaskövi Ágnes (PhD hallgató, Operációkutatás és Aktuáriustudományok Tanszék, Budapesti Corvinus Egyetem)

\section{ÖSSZEFOGLALÓ}

Az idősödő társadalom és az egyre hosszabb várható élettartam különös feladat elé állítja a nyugdíjrendszereket, a biztosítókat és az egyéneket egyaránt. A nyugdíbban töltött évek számának emelkedése olyan kockázatokat rejt, melyek nemcsak a nyugdíjkasszát, de az egyének anyagi biztonságát is jelentős kihívások elé állítják. Jelen tanulmányban a 2018 júniusában megrendezett 31. Nemzetközi Aktuárius Kongresszuson - ebben a témában - elhangzott előadásokat füzöm fel a várható élettartam-emelkedés, nyugdíjkockázatok és a pénzügyi tudatosság fonalára.

\section{SUMMARY}

Aging population and increasing life spans mean significant challenge for pension systems, insurance companies, as well as the individuals. Increasing number of years in retirement imply high level risks for pension schemes and individual financial stability. This study summarizes some of those academic and empirical researches which concentrate on the very actual topic of longevity, pension risks and financial literacy and presented at the 31st International Congress of Actuaries, Berlin, in June 2018.

Kulcsszavak: öregedés, várható élettartam emelkedése, nyugdíj, nyugdíjtudatosság, megtakarítás

Keywords: aging, longevity, pensions, retirement readiness, savings

\section{JEL: E21, H55, J14, G41}

DOI: $10.18530 /$ BK.2018.3.48

http://dx.doi.org/1018530/BK.2018.3.48

\section{Bevezetés}

2018. június 3-8. között került megrendezésre a 31. Nemzetközi Aktuárius Kongresszus (International Congress of Actuaries, ICA) Berlinben. A kongresszuson a világ országainak több mint 2500 aktuáriusa képviseltette magát, az 5 szakmai nap alatt mintegy 280 előadást tartottak kutatók és gyakorlati szakemberek. Az előadások 8 témakörbe szerveződtek: AFIR-ERM (pénzügyi kockázatkezelés), ASTIN (nem-élet biztosítások), IACA (aktuárius tanácsadás), Health (egészségbiztosítás), Life (életbiztosítás), Pension (nyugdíjbiztosítás), Professionalism and data science (szakmaiság, beleértve az adattudományokat) és Education (aktuáriusoktatási kérdések).

Több szekcióban kiemelt figyelmet kapott a hosszabbodó várható élettartam mint egyéni és közösségi kockázati tényező. A témával rendszeresen foglalkozik a hazai aktuárius szakma és a Biztosítás és Kockázat folyóirat (pl. Horváth (2016)) is, elsősorban a közösségi kockázat, azaz a biztosítói kockázat és a nyugdíjrendszerekre nehezedő nyomás oldaláról közelítve a kérdést. A kongresszuson több nemzetközi előadó az egyéni felkészülést és a nyugdíjas évek anyagi biztonságának összefüggéseit vizsgálta. Jelen összefoglalómban az itt elhangzott legfrissebb kutatások eredményeit mutatom be a nyugdíjban töltött évek számának növekedése és az egyéni életpálya pénzügyi stabilitása összefüggésében.

\section{Várható élettartam trendek}

Az elmúlt évtizedekben látványosan nőtt a várható élettartam a férfiaknál és a nőknél egyaránt, továbbá megfigyelhető a keleti országok fokozatos felzárkózása a fejlett világ országaihoz. Általánosságban elmondható, hogy 10 évente mintegy 2,5 évvel nőtt a várható élettartam az OECD országokban, ennek eredményeképpen 2015-ben a férfiak átlagosan 78 évig, míg a nők 83 évig éltek. Ezen országok között a listavezető a férfiak születéskor várható élettartama alapján Izrael, ahol több mint 81 évig éltek a férfiak, míg a nőknél a 87 év várható élettartammal Japán vezeti a listát. Érdekes kiemelni, hogy Európában a svájci és norvég férfiak (80,8, illetve 80,5 év), valamint a spanyol és francia nők (85,8 és 85,5 év) élnek a legtovább.

Az egyik nyitó előadásban a várható élettartam vizsgálatakor Mikko Myskylä (a Max Planck Institute for Demographic Research ügyvezető igazgatója, valamint a Helsinki Egyetem Társadalomstatisztika tanszékének professzora) előadásában bemutatta, hogy a kelet-német nők halandósági rátája alacsonyabb, mint a hajdani Nyugat-Németország területén élő német nőké. Ugyanitt rámutatott arra, hogy a kelet-nyugati egyesítés óta látványos felzárkózás figyelhető meg a várható élettartamot illetően is, amit az egészségügyi ellátások színvonalának javulására, az életszínvonal emelkedésére és a megélhetési stressz csökkenésére vezet vissza a hivatkozott szakirodalom alapián. Mindezen tényezők azonban nem indokolják azt, hogy a keleti halandósági ráta kedvezőbb, mint a nyugati. 
Ennek magyarázatához megvizsgálta a keleti és nyugati életmód eltérő egészségügyi faktorait, és azt találta, hogy a keleten élő nők számottevően később kezdtek dohányozni, mint nyugati társaik, ezáltal a tüdőrák mint az egyik vezető halálok lassabban emelkedett a 2000-es évek elejéig. A trend a két Németország egyesítését követően megfordulni látszik, tekintettel arra, hogy a kelet-német területeken élő nők az 1990-es évektől kezdődően átveszik a vezető szerepet a dohányzást illetően nyugati társaiktól.

Myrskylä fenti megállapításai is megerősítik azt a kutatási irányt, mely szerint nem elegendő a várható élettartamra vonatkozó előrejelzéseket tenni, az egészségesen töltött évek számát befolyásoló tényezők vizsgálatára éppen akkora hangsúlyt kell fektetni. Myrskylä halandósági vizsgálataiban tovább megy, és azt mondja, hogy a következő évtizedek meghatározó egészségügyi tényezője az elhízás lesz, mely a várható élettartamot szignifikánsan lerövidítő dohányzástól eltérően hosszú, de betegségekkel nehezített életet eredményez.

\section{5-ben a várható élettartam növekedési üteme lassult.}

Brian Ridsdale, a Nemzetközi Aktuárius Társaság (International Actuaries Association) halandóság munkacsoportjának elnöke előadásában bemutatta az elmúlt 20 év halandósági trendjeit, és megállapította, hogy 2015-ben a várható élettartam növekedési üteme lassulni látszik. Azt, hogy ez ténylegesen trendfordulót jelent-e, vagy csak megtorpanást, átmeneti lassulást a növekedésben, még korai lenne megállapítani, de a visszaesés okainak vizsgálata mindenképpen szükséges. Ridsdale többek között öt fő tényezőt jelölt meg, melyek valamennyien jelentős mértékben hozzájárulnak a fejlett országok mortalitási rátáinak romlásához. Az első tényező a szezonális halálozás, mely környezetünk, éghajlatunk változására, illetve a járványok (pl. influenza) terjedésére vezethető vissza. A következő jelentős tényező a kiemelt halálokokban keresendő, a szív- és érrendszeri megbetegedések, a demencia és a 15-64 éves korcsoport váratlan (baleseti) halála egyaránt jelentős emelkedést mutat az elmúlt néhány évben. Myrskylähoz hasonlóan kiemeli a dohányzás, elhízás (illetve diabétesz) és egyéb káros szenvedélyek okozta magasabb halálozási rátákat. Negyedik jelentős tényezőként említi a szociológiai és gazdasági különbözőségek miatt kialakult társadalmi leszakadást és az ebből adódó magasabb halálozási rátákat a deprivált társadalmi rétegekben. Ez utóbbit fokozza az ötödikként említett tényező, a kormányzati megszorító politikák hatása, ami a legtöbb fejlett és feltörekvő országban a legszegényebb és leggazdagabb társadalmi rétegek további távolodását eredményezi.

Andrew J.G. Cairns, a Heriot-Watt Egyetem (Edinburgh) pénzügy-matematikus professzora szintén a szociológiai és gazdasági faktoroknak a halálozási rátákra gyakorolt hatását mutatta be előadásában. Kutatótársaival dán halandósági adatokat elemeztek, és vizsgálták az eltérő jövedelmű és iskolázottságú csoportok halálok szerinti eltéréseit. Kutatásuk eredményeképpen megállapították, hogy a legjellemzőbb halálokok, mint a dohányzás, elhízás, alkoholizmus miatt bekövetkező májelégtelenségek vagy akár az egészséges életmód hiánya egyértelmű különbségeket mutatnak a legalacsonyabb és legmagasabb jövedelmü csoportok között. A legszignifikánsabb eltérést a 60 év alattiak korcsoportjaiban találták. Megállapították továbbá, hogy a jövedelmi különbségek jelentősebb eltérést eredményeznek a vizsgált csoportok halálozási rátáiban, mint az iskolai végzettségbeli különbségek. Számos olyan halálokot találtak ugyanakkor, ahol nem volt szignifikáns eltérés sem jövedelmi, sem iskolázottsági szint szerinti csoportok között.

\section{Növekvő élettartam, egyre hosszabb nyugdíjas évek}

Számos empirikus kutatás hívja fel a figyelmet azokra a kockázatokra, melyek a várható élettartam növekedésében rejlenek. Ez az egyén szintjén többrétű is lehet: az egyén alulbecsüli a várható élettartamát, így rövidebb időre tervez, mint szükséges lenne, és túl korán vonul nyugdíjba,

az előzőből következően alulbecsüli a kívánt jólét megteremtéséhez szükséges anyagi fedezetet is,

nem biztosítja magát a megtakarításainak felélése esetére,

nem kalkulál a növekvő infláció esetleges hatásaival, melyek egy 20-30 éves nyugdíjas időszakot tekintve igen jelentősek lehetnek,

nem készül fel megfelelöen a nyugdíjas évek alatt bekövetkező esetleges (egészségügyi) sokkhatásokra, illetve a háztartásban bekövetkező változásokra (házastárs halála).

\section{Az öt nyugdíjpillérből három öngondoskodás-alapú.}

Winfried Heinen, a General Reinsurance AG igazgatótanácsának elnöke előadásában a Föld lakosságának növekvő várható élettartamával összefüggésben a nyugdíjrendszerek fenntarthatóságát vizsgálta. A számos országra jellemző felosztó-kirovó nyugdíjrendszerek jelenlegi formájukban hosszú távon nem fenntarthatók, különösen az olyan elöregedő társadalmakban, mint Japán vagy Németország. A Világbank ajánlása mentén valamennyi országban szükséges lenne mielőbb - az ország nyugdíjrendszerének hagyományait és különbözőségeit figyelembe véve - adaptálni az ötpilléres (0-tól 4. pillérig) nyugdíjszisztémát, mely jelentős hangsúlyt fektet az öngondoskodással elérhető anyagi biztonságra. Az öt nyugdíppillérből három öngondoskodás-alapú. Heinen előadásának legföbb üzenete kettős volt, egyrészt az egyének szintjén a pénzügyi edukáció, másrészt a pénzügyi szolgáltatók szintjén az életbiztositók járulékszolgáltatásának kiemelt fontosságát hangsúlyozta.

\section{Felkészültünk a nyugdíjas évekre?}

Martin Stevenson, az Ausztrál Aktuárius Intézet volt elnöke és Ken Hohman, az Amerikai Aktuárius Akadémia korábbi elnöke mutatta be annak a három angolszász országon átívelő 2017-es kutatásnak az eredményeit, melyben az amerikai, ausztrál és brit munkaképes (18 és 64 év közötti) lakosságot kérdezték meg a nyugdíffelkészültségükről. A kérdőív 16 feleletválasztós 
kérdést, továbbá demográfiai adatokat gyüjtő kérdéseket tartalmazott, az eredményeket ország, életkor, nem és jövedelemosztályok szerint elemezték. A felmérésben három fó témát vizsgáltak:

(i) Nyugdíba vonulással kapcsolatos változások: ugyan a megkérdezettek jelentős része (mintegy $70 \%$-a) tervezi a nyugdíjba vonulást, de nagyobb arányban a fokozatos nyugdíjazást tartják elképzelhetőnek. A nyugdíjba vonulási kor kapcsán nem volt jelentős eltérés a három ország válaszadói között, 70 éves koron túli nyugdíjazást a megkérdezettek mindössze 25 százaléka tartott elképzelhetőnek. Általánosan jellemző mindhárom országra, hogy kevesebb mint 50 százalékban várnak kényelmes, anyagi biztonságban töltött nyugdíjas éveket, inkább alacsony várakozásokkal tekintenek a nyugdíjazásra. Ez az eredmény a vizsgált korcsoportok között nem mutatott eltérést, ugyanakkor a nemek és jövedelmi csoportok között már megfigyelhető volt a szignifikáns különbség (a magas jövedelműek és a férfiak bizakodóbbak, mint az alacsony jövedelműek, illetve a nők). A megkérdezettek várakozásai szerint a nyugdíjas évek anyagi fedezetét az USAban és Nagy-Britanniában elsősorban az állami nyugdíj biztosítja, ezt követi majdnem azonos súllyal a munkáltatói nyugdíj, az egyéni nyugdíj-előtakarékosság és az egyéb egyéni megtakarítások. Ausztráliában eltérő a helyzet, ott a válaszadók leginkább egyéni megtakarításaikra építik nyugdíjas éveik anyagi biztonságát.

(ii) Felkészülés a nyugdijas évekre: a megkérdezettek mintegy 40 százaléka nem készül kielégítő módon a nyugdíjas évekre. Ugyan mindhárom országban jellemző, hogy a megkérdezettek legalább fele képezte/képezi magát valamilyen formában a nyugdíjas évek anyagi kihívásaival kapcsolatban, és alig kevesebb azok száma, akik félre is tesznek. Ugyanakkor arra a kérdésre, hogy pontosan mennyit érdemes félretenni, illetve mikor érdemes nyugdijba vonulni, már csak a megkérdezettek 20-30 százaléka válaszolt magabiztosan. Itt jól észrevehető különbség is mutatkozott az országok között, a brit válaszadók többségében teljesen bizonytalanok a mennyit és mikor kérdésekben. Nem meglepő eredmény, hogy életkorban a nyugdíjkorhatárhoz közelebb lévő válaszadók jobban készülnek, mint a fiatalabbak.

(iii) Nyugdijas évek kockázatainak felmérése és kezelése: általánosságban megállapítható, hogy mindhárom országban hasonlóan felkészületlen a lakosság a nyugdíjas évek kockázataira. A legkevésbé kezelhetö kockázat a nyugdíjas évek hossza, mely ugyan összefüggésben van a várható élettartammal, de az egyén szintjén nem kapcsolódik össze tudatos tervezéssel, lehetséges szcenáriók értékelésével. A kutatás külön kiemeli, hogy a nők mindhárom országban kevésbé vallották magukat felkészültnek a nyugdíjas évek kockázataira, mint a férfiak.

A felmérés eredményei kapcsán a három ország aktuárius intézetei mindenekelőtt a megfelelően megválasztott célcsoportok (középkorúak, közepes anyagi helyzetűek) pénzügyi kultúrájának fejlesztését látják a legfőbb feladatnak amellett, hogy a nyugdíjrendszerek fenntarthatóságát biztosítják.
Heinen, Stevenson, Hohman mellett a konferencia több neves előadója is felhívja a figyelmet az egyének pénzügyi tudatosságának fejlesztésére, kiemelt figyelemmel a nyugdíjtervezésre. Ilyen Ralph Rogalla is, a New York-i St. John's Egyetem adjunktusa, aki érdekes kísérlet eredményét mutatta be a konferencián. Kutatásukban azt vizsgálták, hogy egy egyösszegü „jutalom” felajánlása milyen mértékben befolyásolja a megkérdezetteket nyugdíjba vonulásuk elhalasztásában. Ennek a kérdésnek kifejezett jelentősége van, ha figyelembe vesszük, hogy 2015-ben az USA-ban a leggyakoribb tényleges nyugdíjba vonulási kor 62 év volt, szemben a 65 éves hivatalos nyugdíjkorhatárral, a férfiak 38, míg a nők 44 százaléka igényelte 62 éves korban az állami nyugdíjat. (Magyarországon is hasonló a helyzet, hiszen a hivatalos nyugdíjkorhatár hazánkban is közelít a 65 évhez, de az effektív nyugdíjazási kor 2015-ben férfiaknál átlagosan 63 év, míg a nőknél alig több, mint 60 év volt.) Kérdésfeltevésük tehát a következő volt: elhalasztanák-e az egyének nyugdíjigénylésüket, amennyiben egy - aktuáriusi alapon számított fair - egyösszegű nyugdíjmegváltást kapnának ahelyett, hogy emelkedne a nyugdíjjáradékuk a hosszabb munkában töltött idő alapján. 2500 fös mintán vizsgálták a válaszokat egy online kérdőív alapján. Az empirikus adatok és a válaszok alapján felépített optimumszámítási modell alapján azt találták, hogy mintegy 0,4 évvel későbbre halasztják az egyének a nyugdíjigénylésüket, amennyiben fair összegü nyugdíjmegváltást kapnak. Megállapításuk 13 százalék diszkont mellett is érvényes maradt, azaz csak a fair összeg 87 százalékánál kisebb összeg esetén tűnt el teljesen a halasztási hajlandóság. Az így kitolódó aktív korban képződő jövedelem megnövelheti a társadalombiztosítási rendszer és az államháztartás (adó)bevételeit, egyben kedvező irányt jelenthet a nyugdíjreformok számára.

\section{A nyugdíjasok nem élik fel megtakarításaikat, inkább szinten tartják azokat további befektetésekkel.}

Felix Hentschel, a Viadico tanácsadója a kongresszuson bemutatott PhD disszertációjában azt az igen releváns kérdést vizsgálta, hogy bizonytalan környezetben (növekvő várható élettartam, csökkenő állami nyugdíjvárakozások és alacsony kamatkörnyezet mellett) hogyan tud az egyén optimális döntést hozni a nyugdíjba vonulási idejéről. Modelljében az optimális időzítést három fő paraméter befolyásolja: megtakarítás, fogyasztás és nyugdíjidőzítés. Ez utóbbi két hasznossági függvénnyel írható le: nyugdíjba vonulás előtt szignifikánsan magasabb munkapiaci bevétel és a nyugdíjba vonulást követően megnövekvő szabadidő. Azt találta, hogy a korai nyugdíjba vonulás akkor preferált, ha az egyén nagyra értékeli a nyugdíjas évek alatt jellemzően megnövekvő mennyiségű szabadidőt, vagy ha alacsony életszínvonalon élt nyugdíjazását megelőzően.

Jennifer Alonso-Garcia, az Új-dél-walesi Egyetem adjunktusa, a CEPAR szenior kutatója mutatta be az ICA által díjazott kutatásukat, melyben a nyugdíjas évek alatt jellemző megtakarítási preferenciákat vizsgálták. A tanulmányomban eddig bemutatott 
előadásoktól eltérően ez a kutatás nem a nyugdíjas évekre való felkészülést vizsgálta, hanem annak az elmélet és empíria közötti ellentmondásnak a feltérképezésére tett kísérletet, mely szerint a nyugdíjasok nem élik fel megtakarításaikat, inkább szinten tartják azokat további befektetésekkel. Kérdőíves felmérésükben a CEPAR kutatói arra keresték a választ, hogy a nyugdíjasok megtakarítási szokásait milyen tényezők befolyásolják. Vizsgálatukba ausztrál és holland válaszadókat vontak be, így az országok közötti egyéni motivációs eltéréseket is feltérképezhették. Végül azt vizsgálták, hogy a megtakarítási preferenciák sorrendjére milyen hatással van egy előre nem látható egészségügyi sokk. Hat racionális (elővigyázatosság, egészségügyi kockázatok, élettartam-kockázat, hagyaték, házastársi örökség, fizetőképesség) és négy pszichológiai (függetlenség, biztonság, boldogulás, politikai kockázat) megtakarítási motivációt definiáltak, ezek sorrendjére voltak kíváncsiak. A két ország megkérdezettjeit anyagi helyzetük alapján csoportokra bontották. Azt találták, hogy mindkét országban az egészségügyi kockázatokra való felkészülés és az egyéni boldogulás a legfőbb motivációs tényezők, a hollandoknál ezekhez még a házastársak közötti hagyaték járul harmadik fontos tényezőként, az ausztráloknál pedig a függetlenség. Mindkét országban kevésbé látszik fontosnak a távolabbi jövő motivációja, mint például az élettartam-kockázat és az örökösökre szálló hagyaték mértéke. Megállapították, hogy a két ország eltérő kultúrájából és hagyományaiból adódóan országspecifikus különbségek is felfedezhetők, illetve az egyéni hatásoknak jelentős szerepük van a motivációk sorrendjének meghatározásakor. Nem meglepő eredményre jutottak az előre nem látható egészségügyi sokk hatásának vizsgálatakor, minden megkérdezett esetében előtérbe kerültek az egészségügyi kockázatok miatti megtakarítási preferenciák.

\section{Élettartam-kockázat - hogyan és mit kommunikáljunk?}

A fentiekben bemutatott előadások, kutatások kivétel nélkül arra hívják fel a figyelmet, hogy a nyugdíjtudatosság az egyik legfontosabb pénzügyi feladat, ezt pedig az élettartam-kockázat mértékének ismerete nélkül nehéz felelősen tervezni. Az élettartam-kockázat megértése ugyanakkor igen nehéz feladat, olyan bizonytalanságot takar, melyet az egyén szintjén sok esetben lehetetlen felmérni. Éppen ezért a nyugdíjrendszer állami és magán intézményi szereplőinek jelentős hangsúlyt kell fektetniük arra, hogy a kockázatokat megfelelően kommunikálják, és a lehető legjobban felkészüljenek és felkészítsenek a következő évtizedekben várható folyamatokra.

Ted Goldman, az Amerikai Aktuárius Akadémia (American Academy of Actuaries) partnere és Andrew Peterson, az amerikai Aktuárius Társaság (Society of Actuaries) partnere közös előadásukban a két szervezet által 2016 májusában útjára bocsátott „Actuaries Longevity Illustrator” (Aktuárius Élettartam Modellező) in- teraktív információs webportál tapasztalatait mutatta be. A honlap kiváló eszköz arra, hogy a látogatók jobban megértsék a hosszabbodó várható élettartamban és a nyugdíjas évekre rendelkezésre álló anyagi források felélésében rejlő kockázatokat. Egy ország női/férfi lakosságának várható élettartam mutatója ugyanis mindöszsze egy átlagos szám, mely nyilvánvalóan nem reprezentálja az egyén ténylegesen várható élettartamát. Még fontosabb szempont lehet az is, hogy nem csak egyéni szinten érdemes tervezni a nyugdíjasévek pénzügyi biztonságát - a bizonytalan vár ható élettartam mellett -, hiszen az egy háztartásban élő házastársak, párok közös tervezése pontosabb becslést adhat a jövő lehetséges szcenárióira. A honlap néhány személyes adat megadása után több lehetséges kimenetet vázol fel a felhasználóknak az egyének és párok várható élettartamát figyelembe véve, egyelőre azonban még nem ad útmutatást a lehetséges kimenetekhez kapcsolódó, megnyugtató pénzügyi helyzet kialakításához.

\section{Összefoglalás}

Jelen tanulmányban a 2018 júniusában megrendezett 31. Nemzetközi Aktuárius Kongresszuson elhangzott azon előadásokat foglaltam össze, melyek különböző szempontok alapján az egyéni pénzügyi tudatosság és a hosszabbodó várható élettartam összefüggéseit elemezték. A kutatók, gyakorlati szakemberek egyre sürgetőbben hívják fel a figyelmet a növekvő várható élettartam különös kockázataira, melyek nemcsak a közösség szintjén értelmezendők, hanem az egyén szintjén is kezelendők. Számos empirikus kutatás világít rá arra, hogy az egyének tendenciaszerűen alulbecsülik saját, illetve házastársuk várható élettartamát, így jelentősen kockáztatva a nyugdíjasévek anyagi biztonságát. Figyelembe véve, hogy a nyugdíjban töltött évek száma a korábban jellemző mintegy 15 évről akár meg is duplázódhat, és így várható életünk több mint 30 százalékát nyugdíjasként fogjuk tölteni, belátható, hogy a várható élettartam növekedésének megértése kritikus a nyugdíjtervezés kapcsán. Éppen ezért kiemelt fontosságú a lakosság nyugdíjtudatosságának fejlesztése, még általánosabban a pénzügyi edukáció.

\section{Köszönetnyilvánítás}

A konferenciarészvételt és a jelen tanulmányt az Európai Unió, Magyarország és az Európai Szociális Alap társfinanszírozása által biztosított forrásból az EFOP3.6.2-16-2017-00017 azonosítójú „Fenntartható, intelligens és befogadó regionális és városi modellek” címü projekt finanszírozta. 


\section{IRODALOMJEGYZÉK}

Alonso-Garcia, Jennifer - Bateman, Hazel - Bonekamp, Johan et al (2017): Saving Preferences in Retirement: The Impact of Mandatory Annuitisation, Flexibility and Health Status, https://papers.ssrn.com/sol3/papers.cfm?abstract_id=3184043 (letöltve: 2018. jact Readiness. A Comparative Analysis of Australia, the United Kingdom \& the United States, https://www.actuaries org uk/ documents/retirement-readiness-comparative-analysis-australia-united-kingdom-united-states (letöltve: 2018. július 31.) American Academy of Actuaries, Institute and Faculty of Actuaries (United Kingdom), and Actuaries Institute Australia (2015): The Challenge of Longevity Risk: Making Retirement Income Last a Lifetime, https://www.actuaries.org.uk/documents/ challenge-longevity-risk-making-retirement-income-last-lifetime-0 (letöltve: 2018. július 31.)

Blake, David - Cairns, Andrew J.G. - Dowd, Kevin et al. (2016): Modelling Socio-Economic Differences in the Mortality of Danish Males Using a New Affluence Index, CREATES Research Paper 2016-14, https://pure.au.dk/ws/files/99754100/ rp16_14.pdf (letôltve: 2018. julius 31.)

Chen, An - Hentschel, Felix - Xu, Xian (2018): Optimal retirement time under habit persistence: what makes individuals retire early? Scandinavian Actuarial Journal, 2018: 3, p. 225-249, http://dx.doi.org/10.1080/03461238.2017.1339634

Christie, John - Helman, Ruth (2012): Two Surveys: Understanding and Managing Retirement Risks in Canada and the United States, https://www.soa.org/research/topics/research-post-retirement-needs-and-risks/ (letëlttee: 2018. július 31.) Gallop, Adrian - Ridsdale, Brian (2010): Mortality by Cause of Death and by Socio-Economic and Demographic Stratification
2010, https://www.actuaries.org.uk/search/site/ridsdale (letöltve: 2018. július 31.) Cond doi.org/10.1007/s13524-017-0577-z

Social Security Claiming Behavior under Merer

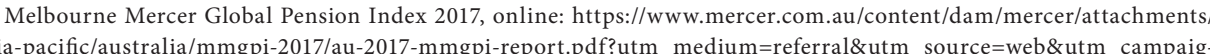
n=mmgpi (letölttve: 2018. július 31.)

http://www.actuary.org/content/actuaries-longevity-illustrator-provide-perspective-retirement-plannin http://www.longevityillustrator.org/

Horváth Gyula (2016): Felkeszültünk a nyugdijra? AEGON nyugdijtudatosság felmérés, Biztositás és Kockázat III. évfolyam,

3. szám http://www.mabisz.hu/hu/esemenyek-publikaciok/648-biztositas-es-kockazat-3-3.html

https://doi.org/10.18530/bk.2016.3.80 